\title{
FAKTOR-FAKTOR YANG MEMPENGARUHI STRUKTUR MODAL PADA PERUSAHAAN REAL ESTATE DAN PROPERTY YANG TERDAFTAR DI BURSA EFEK INDONESIA (BEI)
}

\author{
Syska Lady Sulistyowatie \\ syskaladys@gmail.com
}

\begin{abstract}
ABSTRAK
"Factors Affecting Capital Structure In Real Estate and Property Company Listed on the Indonesia Stock Exchange (BEI)".
\end{abstract}

This empirical study was aimed to determine the effect of Asset Structure, Profitability (ROA), Liquidity (Current Ratio), Company Size, Growth Rate, Growth Opportunities, Managerial Ownership, and Business Risk on Capital Structure of Real Estate and Property Company listed on the Indonesia Stock Exchange (BEI).

Based on the results of data analysis, hypothesis testing indicated that all of the variables including Asset Structure, Profitability (ROA), Liquidity (Current Ratio), Company Size, Growth Rate, Growth Opportunities, Managerial Ownership, and Business Risk simultaneously influenced the Capital Structure of Real Estate and Property Company listed on the Indonesia Stock Exchange (BEI) with p-value of F test 0.000. The test result partially showed that asset structure variables, firm size, and growth opportunities gave positive and significant effect on the Capital Structure (Debt to Equity Ratio), Variable Profitability (ROA), Liquidity (Current Ratio), Growth Rate, Managerial Ownership and Risk Business did not affect the Capital Structure (Debt to Equity Ratio). Based on the coefficient determination testing, it can be seen that the proportion of all variables contribution on Capital Structure was $8.9 \%$.

Keywords: Capital Structure, Trade off Theory and Pecking Order Theory

\subsection{Latar Belakang}

Kelangsungan usaha atau operasi dari suatu perusahaan dapat berjalan dengan baik jika manajer keuangan dapat secara tepat dan teliti mengambil keputusan dari sumber pendanaan, baik yang berasal dari dalam perusahaan maupun dari luar perusahaan. Dana yang berasal dari dalam perusahaan adalah dana yang dihasilkan oleh perusahaan itu sendiri yaitu laba ditahan dan depresiasi. Sedangkan dana yang diperoleh dari luar perusahaan adalah dana yang berasal dari kreditur (Wardani, 2010). Keputusan pendanaan tersebut merupakan keputusan pendanaan yang mampu meminimalkan biaya modal yang harus ditanggung perusahaan. Sehingga biaya modal yang timbul dari keputusan pendanaan merupakan konsekuensi yang secara langsung timbul dari keputusan yang dilakukan manajer. Ketika manajer menggunakan hutang, jelas 
biaya modal yang timbul sebesar biaya bunga yang dibebankan oleh kreditur. Sedangkan jika manajer menggunakan dana internal atau dana sendiri akan timbul opportunity cost dari dana atau modal sendiri yang digunakan.

Banyak penelitian mengenai faktor-faktor yang mempengaruhi pemilihan struktur modal perusahaan, seperti penelitian yang dilakukan Prabansari dan Kusuma (2005), Utami (2009), Febriyani dan Srimindarti (2010), Seftianne dan Handayani (2011) serta Indrajaya, Herlina dan Setiadi (2011). Perbedaan antara penelitian terdahulu terlihat didalam penggunaan faktor yang diteliti maupun hasil penelitian masing-masing.

Berawal dari permasalahan kegagalan pembayaran kredit perumahan (subprime mortgage default) di Amerika Serikat (AS), krisis kemudian menggelembung merusak sistem perbankan bukan hanya di AS namun meluas hingga ke Eropa lalu ke Asia. Rakyat Amerika hidup dalam konsumerisme di luar batas kemampuan pendapatan yang diterimanya. Mereka hidup dalam hutang, belanja dengan kartu kredit, dan kredit perumahan. Akibatnya lembaga keuangan yang memberikan kredit tersebut bangkrut karena kehilangan likuiditasnya dan piutang perusahaan kepada para kreditor perumahan telah digadaikan kepada lembaga pemberi pinjaman.

Berdasarkan uraian di atas, maka penelitian ini menetapkan obyek yang akan diteliti dikhususkan pada perusahaan Real Estate dan Property yang terdaftar di Bursa Efek Indonesia (BEI). Penetapan kelompok saham perusahaan Real Estate dan Property sebagai obyek penelitian dimaksudkan untuk menganalisis apakah struktur modal kelompok ini secara empiris juga mempunyai keterkaitan seperti halnya untuk kelompok sektor perusahaan pada umumnya seperti sektor manufaktur dan bagaimana struktur modal perusahaan pada sektor Real Estate dan Property khususnya di Indonesia pasca krisis ekonomi global di Amerika Serikat. Kelebihan penelitian ini adalah sampel dan variabelnya telah mengalami penambahan menjadi lebih banyak dari penelitian sebelumnya serta periode waktu pengamatan yang lebih lama.

\subsection{Rumusan Masalah}

Berdasarkan pada latar belakang yang sudah dijelaskan sebelumnya, maka rumusan masalah dalam penelitian ini yaitu :

1. Bagaimana pengaruh struktur aktiva terhadap struktur modal pada perusahaan Real Estate dan Property yang terdaftar di Bursa Efek Indonesia (BEI)?

2. Bagaimana pengaruh profitabilitas terhadap struktur modal pada perusahaan Real Estate dan Property yang terdaftar di Bursa Efek Indonesia (BEI)?

3. Bagaimana pengaruh likuiditas terhadap struktur modal pada perusahaan Real Estate dan Property yang terdaftar di Bursa Efek Indonesia (BEI)?

4. Bagaimana pengaruh ukuran perusahaan terhadap struktur modal pada perusahaan Real Estate dan Property yang terdaftar di Bursa Efek Indonesia (BEI)?

5. Bagaimana pengaruh tingkat pertumbuhan terhadap struktur modal pada perusahaan Real Estate dan Property yang terdaftar di Bursa Efek Indonesia (BEI)? 
6. Bagaimana pengaruh peluang pertumbuhan terhadap struktur modal pada perusahaan Real Estate dan Property yang terdaftar di Bursa Efek Indonesia (BEI)?

7. Bagaimana pengaruh kepemilikan managerial terhadap struktur modal pada perusahaan Real Estate dan Property yang terdaftar di Bursa Efek Indonesia (BEI)?

8. Bagaimana pengaruh risiko bisnis terhadap struktur modal pada perusahaan Real Estate dan Property yang terdaftar di Bursa Efek Indonesia (BEI)?

\subsection{Tujuan Penelitian}

Sesuai dengan rumusan masalah diatas, penelitian ini bertujuan untuk:

1. Menganalisis pengaruh struktur aktiva terhadap struktur modal pada perusahaan Real Estate dan Property yang terdaftar di Bursa Efek Indonesia (BEI).

2. Menganalisis pengaruh profitabilitas terhadap struktur modal pada perusahaan Real Estate dan Property yang terdaftar di Bursa Efek Indonesia (BEI).

3. Menganalisis pengaruh likuiditas terhadap struktur modal pada perusahaan Real Estate dan Property yang terdaftar di Bursa Efek Indonesia (BEI).

4. Menganalisis pengaruh ukuran perusahaan terhadap struktur modal pada perusahaan Real Estate dan Property yang terdaftar di Bursa Efek Indonesia (BEI).

5. Menganalisis pengaruh tingkat pertumbuhan terhadap struktur modal pada perusahaan Real Estate dan Property yang terdaftar di Bursa Efek Indonesia (BEI).

6. Menganalisis pengaruh peluang pertumbuhan terhadap struktur modal pada perusahaan Real Estate dan Property yang terdaftar di Bursa Efek Indonesia (BEI).

7. Menganalisis pengaruh kepemilikan managerial terhadap struktur modal pada perusahaan Real Estate dan Property yang terdaftar di Bursa Efek Indonesia (BEI).

8. Menganalisis pengaruh risiko bisnis terhadap struktur modal pada perusahaan Real Estate dan Property yang terdaftar di Bursa Efek Indonesia (BEI).

\subsection{Manfaat Penelitian}

Hasil penelitian ini diharapkan dapat memberikan manfaat sebagai berikut:

1. Bagi Investor

Hasil penelitian ini diharapkan dapat memberikan kontribusi mengenai faktor-faktor yang mempengaruhi struktur modal. Faktor-faktor tersebut sebagai kebijakan dalam struktur modal perusahaan yang dapat memaksimalkan harga saham yang merupakan cerminan dari suatu nilai perusahaan.

2. Bagi Emiten 
Hasil penelitian ini diharapkan dapat memberikan kontribusi berupa pengetahuan bagi emiten mengenai keputusan pendanaan didalam perusahaan. Keputusan pendanaan didalam perusahaan adalah masalah struktur modal dan merupakan masalah penting bagi perusahaan, karena baik buruknya struktur modal akan mempunyai efek langsung terhadap posisi finansial perusahaan.

3. Bagi Manager Keuangan

Hasil penelitian ini diharapkan dapat memberikan kontribusi dalam mengambil langkah-langkah yang diperlukan manager keuangan untuk menentukan kebijakan pendanaan atau kebijakan dalam struktur modal perusahaan yang dapat memaksimalkan harga saham yang merupakan cerminan dari suatu nilai perusahaan.

4. Bagi Dunia Akademis

Hasil penelitian ini diharapkan dapat menambah pengetahuan mengenai faktor-faktor yang mempengaruhi struktur modal perusahaan serta dapat digunakan sebagai referensi untuk penelitian berikutnya.

\section{KAJIAN PUSTAKA}

\subsection{Struktur Modal}

Struktur modal merupakan masalah yang penting dalam pengambilan keputusan mengenai pembelanjaan perusahaan karena secara langsung berakibat terhadap biaya modal, keputusan tentang capital budgeting dan harga pasar. Struktur modal ditentukan oleh perbandingan antara hutang jangka panjang dan modal sendiri yang digunakan oleh perusahaan. Manajer keuangan harus secara hati-hati memantau efek dari struktur modal terhadap profit yang diperoleh. Struktur modal perusahaan haruslah memaksimumkan profit bagi kepentingan modal sendiri, dan keuntungan yang diperoleh haruslah lebih besar daripada biaya modal sebagai akibat penggunaaan struktur modal tertentu (Alwi, 1980).

Struktur modal (Weston dan Copeland, 1999), adalah cara bagaimana perusahaan membiayai aktivanya. Struktur modal dapat dilihat pada seluruh sisi kanan neraca. Ini terdiri dari hutang jangka pendek, hutang jangka panjang dan modal pemegang saham. Struktur modal atau permodalan perusahaan adalah pembiayaan permanen yang terdiri dari hutang jangka panjang, saham preferen dan modal pemegang saham. Jadi struktur modal suatu perusahaan hanya merupakan sebagian dari struktur pembiayaannya.

\subsection{Struktur Aktiva}

Struktur aktiva adalah sebagai perbandingan antara aktiva tetap dengan total aktiva yang dimiliki oleh perusahaan (Pandey, 2004). Struktur aktiva mempengaruhi sumber-sumber pembiayaan melalui beberapa cara. Perusahaan yang memiliki aktiva tetap jangka panjang banyak menggunakan hutang jangka panjang terutama jika permintaan akan produknya sangat meyakinkan. Perusahaan yang sebagian besar aktivanya berupa aktiva lancar, tidak begitu bergantung pada pembiayaan utang jangka panjang tetapi lebih tergantung pada pembiayaan jangka pendek (Weston dan Copeland, 1999). 
Aktiva tetap dapat dijadikan jaminan dalam melakukan pinjaman utang, dan karenanya dapat mereduksi biaya dari kesulitan keuangan (cost of financial distress) dan ini akan semakin meningkatkan kapastitas tingkat hutang yang dapat menguntungkan perusahaan (Elsas dan Florysiak, 2008). Nilai likuidasi aktiva tetap biasanya akan lebih tinggi dari pada aktiva tidak berwujud (intangible asset), sehingga ketika perusahaan mengalami kebangkrutan, biaya kesulitan keuangan (cost of financial distress) yang ditanggung oleh perusahaan lebih kecil dibandingkan jika perusahaan tersebut memiliki aktiva tidak berwujud lebih tinggi (Gaud, 2003).

\subsection{Profitabilitas}

Perusahaan dengan tingkat return on assets yang tinggi, umumnya menggunakan hutang dalam jumlah yang relatif sedikit. Hal ini disebabkan dengan return on assets yang tinggi tersebut, memungkinkan bagi perusahaan melakukan permodalan dengan laba ditahan saja. Akan tetapi tidak itu saja, asumsi yang lain mengatakan dengan return on assets yang tinggi, berarti bahwa laba bersih yang dimiliki perusahaan tinggi, maka apabila perusahaan menggunakan hutang yang besar tidak akan berpengaruh terhadap struktur modal, karena kemampuan perusahaan dalam membayar bunga tetap juga tinggi. Tingkat pengembalian yang tinggi memungkinkan untuk membiayai sebagian besar kebutuhan pendanaan dengan dana yang dihasilkan secara internal. Hal ini sejalan dengan pecking order theory yang mengemukakan bahwa perusahaan cenderung mempergunakan sumber pendanaan internal sebanyak mungkin sebelum memutuskan untuk berhutang (Kesuma, 2009).

\subsection{Likuiditas}

Rasio likuiditas adalah rasio yang digunakan untuk mengukur kemampuan perusahaan didalam membayar hutang jangka pendek yang segera jatuh tempo. Perusahaan yang dapat segera mengembalikan utang-utangnya akan mendapat kepercayaan dari kreditur untuk menerbitkan utang dalam jumlah yang besar. Kebutuhan dana untuk aktiva lancar pada prinsipnya dibiayai dengan kredit jangka pendek. Sehingga semakin likuid suatu perusahaan, maka semakin tinggi penggunaan hutangnya (Riyanto, 2008). Namun perusahaan dengan tingkat likuiditas tinggi mempunyai dana internal yang besar, sehingga perusahaan tersebut akan menggunakan dana internalnya terlebih dahulu untuk membiayai investasinya sebelum menggunakan pembiayaan eksternal melalui hutang. Likuiditas asset perusahaan dapat digunakan untuk menunjukkan seberapa besar asset tersebut dapat dimanipulasi oleh shareholders dengan biaya yang ditanggung oleh boundholders (Prowse, 1990 dalam Seftiane dan Handayani, 2011).

\subsection{Ukuran Perusahaan}

Ukuran perusahaan menggambarkan besar kecilnya suatu perusahaan. Penentuan besar kecilnya skala perusahaan dapat ditentukan berdasarkan total penjualan dengan total aktiva, rata-rata tingkat penjualan dan rata-rata total aktiva (Mardiana, 2005). Perusahaan dengan ukuran yang lebih besar dan kompleks tidak mempunyai kendala untuk mendapatkan dana eksternal (hutang). Oleh karena itu, kemungkinan tingkat leverage pada perusahaan besar akan 
lebih besar daripada perusahaan kecil. Semakin besar suatu perusahaan, ada kecenderungan untuk menggunakan jumlah pinjaman yang lebih besar (Christianti, 2006).

Berdasar pada static trade off, ukuran perusahaan (size) berpengaruh positif terhadap leverage. Hal ini disebabkan perusahaan dengan ukuran besar mempunyai risiko kebangkrutan yang kecil dibandingkan dengan perusahaan level yang lebih kecil. Berdasarkan pecking order teory dalam hubungannya dengan ukuran perusahaan, struktur modal mempunyai pengaruh negatif terhadap ukuran perusahaan. Perusahaan dengan level yang lebih kecil mempunyai asymetric information yang tinggi dan sedikit untuk mendapatkan sumber dana eksternal (Frank, 2003).

\subsection{Tingkat Pertumbuhan}

Berdasarkan pecking order theory terdapat dua sinyal yaitu, perusahaan dengan tingkat pertumbuhan yang tinggi akan cenderung untuk menjaga dan mempertahankan rasio hutang pada level yang rendah (sinyal negatif) atau perusahaan dengan tingkat pertumbuhan yang tinggi akan melakukan ekspansi dengan cara menggunakan dana eksternal berupa hutang atau sebagai sinyal positif (Christianti, 2006). Kedua sinyal tersebut sebagai kompleksitas dari pecking order theory. Namun, penelitian ini menganggap bahwa atribut pertumbuhan (growth) berpengaruh secara negatif terhadap leverage perusahaan (sinyal negatif). Suatu perusahaan yang berada dalam industri yang mempunyai laju pertumbuhan yang tinggi harus menyediakan modal yang cukup untuk membelanjai perusahaan (Fama, 2002). Perusahaan yang bertumbuh pesat cenderung lebih banyak menggunakan hutang daripada perusahaan yang bertumbuh secara lambat (Brigham dan Gaperski, 1995). Jumlah hutang yang dikeluarkan oleh perusahaan berbanding terbalik dengan pertumbuhan (Ozkan, 2001).

\subsection{Peluang Pertumbuhan}

Peluang pertumbuhan (growth opportunity) adalah perubahan total aktiva yang dimiliki perusahaan (Kartini dan Arianto dalam Febriyani dan Srimindarti, 2010). Peluang pertumbuhan merupakan ukuran sampai sejauh mana laba per lembar saham suatu perusahaan dapat ditingkatkan oleh leverage. Perusahaan-perusahaan yang memiliki pertumbuhan yang cepat seringkali harus meningkatkan aktiva tetapnya. Dengan demikian perusahaan dengan tingkat pertumbuhan yang tinggi lebih banyak membutuhkan dana di masa depan dan juga lebih banyak mempertahankan laba (Febriyani danSrimindarti, 2010). Perusahaan dengan pertumbuhan yang cepat harus banyak mengandalkan pada modal eksternal.P erusahaan dengan pertumbuhan yang tinggi cenderung lebih banyak menggunakan hutang dibanding dengan perusahaan yang lambat pertumbuhannya. Kesempatan yang dimiliki untuk berkembang dan melakukan investasi pada masa mendatang menyebabkan nilai perusahaan akan meningkat. Perusahaan dengan tingkat pertumbuhan potensial yang tinggi tentunya memiliki tingkat kecenderungan untuk menghasilkan arus kas yang tinggi dimasa yang akan datang sehingga memungkinkan perusahaan memiliki biaya modal yang rendah.

\subsection{Kepemilikan Managerial}

Terdapat beberapa alternatif yang digunakan untuk mengurangi biaya keagenan (agency cost), salah satunya adalah dengan meningkatkan kepemilikan saham perusahaan oleh 
manajemen dan selain itu manager merasakan langsung manfaat dari keputusan yang diambil dan juga apabila ada kerugian yang timbul sebagai konsekuensi dari pengambilan keputusan yang salah. Kepemilikan ini akan mensejajarkan kepentingan manajemen dengan pemegang saham (Wahidawati dalam Seftianne, 2011). Istilah struktur kepemilikan digunakan untuk menunjukkan bahwa variabel-variabel yang penting dalam struktur modal tidak hanya ditentukan dengan jumlah hutang dan ekuitas tetapi juga oleh prosentase kepemilikan oleh manager dan institusional (Jensen and Meckling dalam Seftianne, 2011).

\subsection{Risiko Bisnis}

Risiko bisnis merupakan risiko dasar yang dimiliki perusahaan selain financial risk sebagai tambahan risiko perusahaan akibat penggunaan hutang.

Risiko bisnis merupakan risiko dari perusahaan saat tidak mampu menutupi biaya operasionalnya dan dipengaruhi oleh stabilitas pendapatan dan biaya. Perusahaan dengan risiko bisnis yang tinggi cenderung menghindari pendanaan dengan menggunakan hutang dibandingkan dengan perusahaan dengan risiko bisnis yang lebih rendah (Gitman, 2009). Dunia investasi mengenal risiko bisnis sebagai bagian dari risk premium, yang diartikan sebagai ketidakpastian aliran pendapatan yang disebabkan oleh sifat alami dari bisnis itu sendiri seperti produk, pelanggan dan dan cara menghasilkan produknya (Brown dan Reilly, 2009). Perusahaan dengan cash flow yang sangat fluktuatif akan membuat penggunaan hutang yang penuh risiko menjadi kurang menguntungkan apabila dibandingkan dengan ekuitas, sehingga perusahaan harus menggunakan ekuitas untuk memenuhi pendanaan perusahaan dan untuk menghindari financial distress (Setiawan, 2006).

\subsection{Pengembangan Hipotesis}

2.4.1. Pengaruh Struktur Aktiva terhadap Struktur Modal

Struktur aktiva menggambarkan sebuah perbandingan antara aktiva tetap dengan total aktiva yang dimiliki oleh suatu perusahaan. Aktiva tetap atau aktiva berwujud yang semakin besar akan menunjukkan kemampuan perusahaan dalam memberikan jaminan yang lebih tinggi, sehingga dengan mengasumsikan semua faktor lain konstan, perusahaan akan meningkatkan hutang untuk mendapatkan keuntungan dari penggunaan hutang.

$H_{1}$ : Struktur Aktiva mempunyai pengaruh positif terhadap Struktur Modal

\subsubsection{Pengaruh Profitabilitas terhadap Struktur Modal}

Profitabilitas merupakan kemampuan perusahaan dalam menghasilkan laba. Kemampuan perusahaan ini dapat diukur melalui perhitungan rasio pada tingkat penjualan (profit margin), aktiva yang dimiliki (return on total asets), dan modal saham tertentu (return on equity). Dalam penelitian ini, profitabilitas diukur dengan Return On Assets. Perusahaan dengan tingkat Return On Assets yang tinggi, umumnya menggunakan hutang dalam jumlah yang relatif sedikit. Hal ini disebabkan dengan Return On Assets yang tinggi tersebut memungkinkan perusahaan melakukan permodalan dengan laba ditahan saja.

$\mathrm{H}_{2}$ : Profitabilitas mempunyai pengaruh negatif terhadap Struktur Modal

\subsubsection{Pengaruh Likuiditas terhadap Struktur Modal}

Rasio likuiditas adalah rasio yang digunakan untuk mengukur kemampuan perusahaan didalam membayar hutang jangka pendek yang segera jatuh tempo. Berdasarkan pecking order 
theory, perusahaan yang memiliki likuiditas yang tinggi cenderung tidak menggunakan pembiayaan dari hutang.

$H_{3}$ : Likuiditas mempunyai pengaruh negatif terhadap Struktur Modal

\subsubsection{Pengaruh Ukuran Perusahaan terhadap Struktur Modal}

Ukuran perusahaan menggambarkan besar kecilnya suatu perusahaan. Penentuan besar kecilnya skala perusahaan dapat ditentukan berdasarkan total penjualan dengan total aktiva, rata-rata tingkat penjualan dan rata-rata total aktiva (Mardiana, 2005). Perusahaan dengan ukuran yang lebih besar dan kompleks tidak mempunyai kendala untuk mendapatkan dana eksternal (hutang). Oleh karena itu, kemungkinan tingkat leverage pada perusahaan besar akan lebih besar daripada perusahaan kecil. Semakin besar suatu perusahaan, ada kecenderungan untuk menggunakan jumlah pinjaman yang lebih besar (Christianti, 2006).

\section{$H_{4}$ : Ukuran Perusahaan mempunyai pengaruh positif terhadap Struktur Modal}

\subsubsection{Pengaruh Tingkat Pertumbuhan terhadap Struktur Modal}

Tingkat Pertumbuhan adalah kemampuan perusahaan untuk meraih profit materi dan profit non-materi sesuai target. Perusahaan yang bertumbuh pesat cenderung lebih banyak menggunakan hutang daripada perusahaan yang bertumbuh secara lambat (Brigham dan Gaperski, 1995).

$H_{5}$ : Tingkat Pertumbuhan mempunyai pengaruh positif terhadap Struktur Modal

\subsubsection{Pengaruh Peluang Pertumbuhan terhadap Struktur Modal}

Peluang pertumbuhan merupakan ukuran sampai sejauh mana laba per lembar saham suatu perusahaan dapat ditingkatkan oleh leverage. Perusahaan-perusahaan yang memiliki pertumbuhan yang cepat seringkali harus meningkatkan aktiva tetapnya. Dengan demikian perusahaan dengan tingkat pertumbuhan yang tinggi lebih banyak membutuhkan dana di masa depan dan juga lebih banyak mempertahankan laba (Febriyani dan Srimindarti, 2010).

$H_{6}$ : Peluang Pertumbuhan mempunyai pengaruh positif terhadap Struktur Modal

\subsubsection{Pengaruh Kepemilikan Managerial terhadap Struktur Modal}

Terdapat beberapa alternatif yang digunakan untuk mengurangi biaya keagenan (agency cost), salah satunya adalah dengan meningkatkan kepemilikan saham perusahaan oleh manajemen agar manager merasakan langsung manfaat dari keputusan yang diambil dan juga apabila ada kerugian yang timbul sebagai konsekuensi dari pengambilan keputusan yang salah. Kepemilikan ini akan mensejajarkan kepentingan manajemen dengan pemegang saham (Wahidawati dalam Seftianne, 2011).

H7: Kepemilikan Managerialmempunyai pengaruh negatif terhadap Struktur Modal

\subsubsection{Pengaruh Risiko Bisnis terhadap Struktur Modal}

Semakin tinggi risiko bisnis, maka kemungkinan terjadinya financial distress (kesulitan keuangan) juga semakin tinggi ketika perusahaan menggunakan banyak hutang (Krishnan dan Moyers dalam Indrajaya, Herlina dan Setiadi, 2011). Hal tersebut dikarenakan earning yang tidak menentu akan menyebabkan arus kas masuk yang tidak menentu pula. Jika perusahaan 
rugi atau arus kas yang masuk tidak mencukupi untuk membayar beban bunga, maka perusahaan dapat bangkrut.

$H_{8}$ : Risiko Bisnis mempunyai pengaruh negatif terhadap Struktur Modal

\title{
2.5. Kerangka Teori
}

\author{
Gambar 2.1.
}

Kerangka Teori

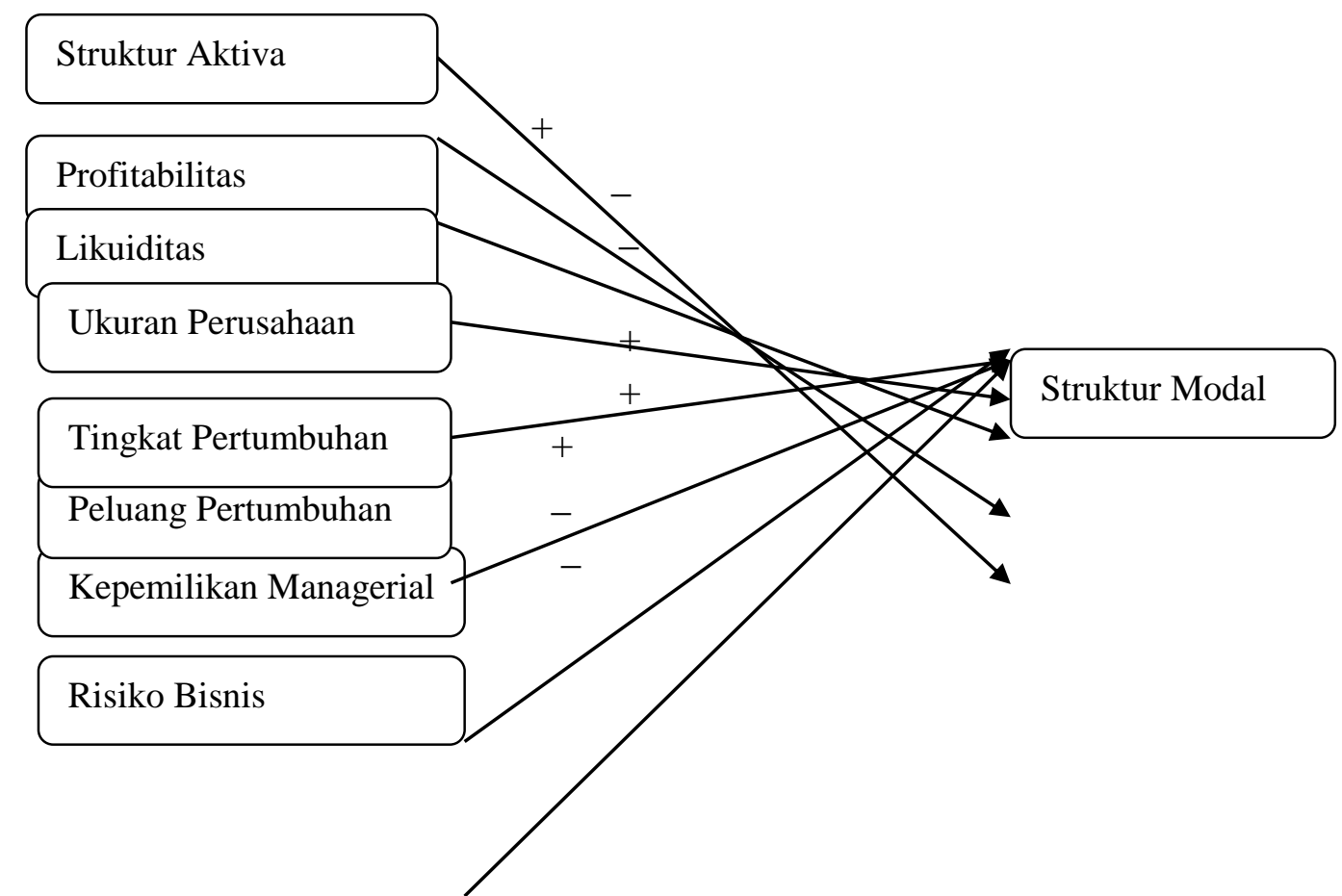

\section{METODE PENELITIAN}

\subsection{Populasi dan Sampel Penelitian}

Populasi yang digunakan dalam penelitian ini adalah semua perusahaan Real Estate dan Property yang terdaftar di Bursa Efek Indonesia (BEI) tahun 2008-2012. Pengambilan sampel dalam penelitian ini dilakukan dengan menggunakan metode purposive sampling. Kriteria perusahaan yang dijadikan sampel dalam penelitian ini adalah :

1. Perusahaan Real Estate dan Property yang terdaftar di Bursa Efek Indonesia (BEI) tahun 2008-2012.

2. Mempublikasikan laporan keuangan periodik pada periode pengamatan tahun 2008 hingga tahun 2012.

3. Perusahaan memiliki semua data yang diperlukan dalam penelitian ini, perusahaanperusahaan yang pada tahun tertentu datanya tidak lengkap, tidak dapat dimasukkan menjadi sampel penelitian ini.

Rincian jumlah perusahaan sampel yang memenuhi kriteria dan digunakan dalam penelitian ini adalah sebagai berikut:

Tabel 3.1.

Perincian Perhitungan Sampel Tahun 2008-2012 


\begin{tabular}{|c|c|c|c|c|c|}
\hline \multicolumn{6}{|c|}{ Jumlah Sampel Perusahaan } \\
\hline \multirow{2}{*}{ Keterangan (Kriteria) } & \multicolumn{5}{|c|}{ Tahun } \\
\hline & 2008 & 2009 & 2010 & 2011 & 2012 \\
\hline $\begin{array}{l}\text { Jumlah populasi perusahaan real estate dan } \\
\text { property yang terdaftar di Bursa Efek Indonesia } \\
\text { (BEI). }\end{array}$ & 49 & 50 & 52 & 52 & 44 \\
\hline $\begin{array}{l}\text { Perusahaan yang tidak mengungkapkan data } \\
\text { secara lengkap terkait dengan data yang } \\
\text { diperlukan. }\end{array}$ & (4) & (4) & (8) & (7) & (4) \\
\hline Perusahaan yang memenuhi kriteria & 45 & 46 & 44 & 45 & 40 \\
\hline Jumlah Observasi & \multicolumn{5}{|c|}{220} \\
\hline
\end{tabular}

\subsection{Jenis dan Sumber Data}

Data yang digunakan adalah data sekunder, yaitu jenis data yang diperoleh secara tidak langsung dari sumber utama (perusahaan). Data dalam penelitian ini berupa Laporan Keuangan Perusahaan Real Estate dan Property yang menjadi obyek penelitian serta data lainnya yang berkaitan dengan penelitian.

Sumber data yang digunakan dalam penelitian ini adalah data laporan keuangan pada perusahaan Real Estate dan Property yang terdaftar di Bursa Efek Indonesia (BEI) yang diperoleh dari data rekapan Laporan Keuangan yang diambil dari Pojok Bursa Efek Indonesia FE UII, Indonesian Capital Market Directory (ICMD) tahun 2009, 2010, 2011, 2012 dan jurnal-jurnal penelitian, dan sumber lain yang relevan sebagai data pendukung.

\subsection{Definisi Operasional Variabel Penelitian}

a. Struktur modal

Struktur modal dalam penelitian ini akan diproksikan dengan Debt To Equity Ratio (DER). Rasio perbandingan antara total kewajiban dengan total modal sendiri. Formula Debt To Equity Ratio dapat dirumuskan:

$D E R=\frac{\text { Total Kewajiban Jangka Panjang }}{\text { Total Modal Sendiri }}$

b. Struktur aktiva

Struktur aktiva akan diukur dengan menggunakan hasil bagi antara aktiva tetap dengan total aktiva. Formula Struktur Aktiva dapat dirumuskan:

Struktur Aktiva $=\frac{\text { Aktiva Tetap }}{\text { Total Aktiva }}$

c. Profitabilitas

Profitabilitas dalam penelitian ini akan diproksikan dengan Return On Assets (ROA). Return On Assets adalah rasio yang digunakan untuk mengukur efektivitas perusahaan dalam 
menghasilkan keuntungan dengan memanfaatkan aktiva yang dimiliki. Formula Return On Assets dapat dirumuskan:

ROA $=\frac{\text { Earning After Tax }}{\text { Total Aktiva }} \times 100 \%$

\section{d. Likuiditas}

Likuiditas dalam penelitian ini akan diproksikan dengan Current Ratio (CR). Current Ratio adalah rasio yang digunakan untuk mengukur kemampuan perusahaan didalam membayar hutang jangka pendek dengan aktiva lancar. Formula Current Ratio dapat dirumuskan:

Current Ratio $=\frac{\text { Aktiva Lancar }}{\text { Kewajiban Lancar }}$

e. Ukuran Perusahaan

Ukuran perusahaan (Firm Size), dalam penelitian ini menggunakan nilai buku dari total asset, sebagai proxy Firm Size. Mengingat nilai aktiva perusahaan yang besar, maka dalam proses penghitungan, nilai total aktiva dihitung dalam jutaan rupiah serta ditransformasikan ke dalam bentuk logaritma natural (Ln). Formula Ukuran Perusahaan dapat dirumuskan:

Firm Size $=$ Ln Total aktiva

\section{f. Tingkat Pertumbuhan}

Tingkat pertumbuhan (Growth) menggunakan persentase perubahan pada total aktiva dari tahun (t-1) terhadap tahun sekarang $(\mathrm{t})$. Formula Tingkat Pertumbuhan dapat dirumuskan:

Tingkat Pertumbuhan $=\frac{\text { Total aktiva }(t)-\text { Total Aktiva }(t-1)}{\text { Total Aktiva }(t-1)}$

Dimana:

Total aktiva ( $\mathrm{t}) \quad$ : Nilai total aktiva pada tahun bersangkutan

Total aktiva (t-1) : Nilai total aktiva satu tahun sebelum tahun yang bersangkutan

g. Peluang pertumbuhan (Growth Opportunity)

Peluang pertumbuhan adalah kesempatan yang dimiliki oleh perusahaan dalam mengembangkan dirinya dalam pasar. Variabel ini didefinisikan sebagai rasio harga pasar per lembar saham pada penutupan akhir tahun dibagi nilai buku per lembar saham. Adapun rumus dari variabel ini adalah:

Growth $=\frac{\text { Harga Penutupan Akhir Tahun Per Lembar Saham }}{\text { Nilai Buku Per Lembar Saham }}$

\section{h. Kepemilikan Managerial (DMOWN)}

Kepemilikan Managerial (DMOWN) adalah jumlah pemegang saham dari pihak manajemen yang secara aktif ikut dalam pengambilan keputusan perusahaan. Karena terdapat 
kecenderungan data di Indonesia bersifat binomial (ada atau tidak ada) maka dalam pengukuran digunakannya dummy variabel. D 1 untuk perusahaan yang terdapat kepemilikan managerial dan D 0 untuk perusahaan yang tidak ada kepemilikan managerialnya.

\section{a. Risiko Bisnis}

Risiko bisnis (RISK) merupakan ketidakpastian yang dihadapi perusahaan dalam menjalankan usahanya (Saidi, 2004). Apabila perusahaan memiliki biaya operasi tetap atau biaya modal tetap, maka dikatakan perusahaan menggunakan leverage. Dengan menggunakan operating leverage, perusahaan mengharapkan bahwa perubahan penjualan akan mengakibatkan perubahan laba sebelum bunga dan pajak yang lebih besar. Multiplier effect hasil penggunaan biaya operasi tetap terhadap laba sebelum bunga dan pajak disebut dengan Degree of Operating Leverage atau disingkat menjadi DOL (Sartono, 2000). Proksi risiko bisnis menggunakan degree of operating leverage dan dapat dirumuskan:

DOL Pada $X=\frac{\% \text { Perubahan EBIT }}{\% \text { Perubahan Penjualan }} \quad$ atau $\quad \frac{\frac{\triangle E B I T}{E B I T}}{\frac{\triangle \text { Penjualan }}{\text { Penjualan }}}$

Dimana: $\Delta$ EBIT $\quad=$ Perubahan EBIT

$\Delta$ Penjualan $=$ Perubahan penjualan

Semakin besar DOL, berarti semakin besar pengaruh perubahan penjualan terhadap EBIT yang berarti bahwa semakin besar DOL maka semakin besar tingkat risiko.

\subsection{Teknik Analisis Data}

\subsubsection{Persamaan Regresi Berganda}

Analisis regresi linier berganda di gunakan untuk memperoleh gambaran yang menyeluruh mengenai pengaruh antara variabel independen terhadap variabel dependen,yang dirumuskan sebagai berikut:

$D E R=a+b_{1} S A+b_{2} R O A+b_{3} C R+b_{4}$ Size $+b_{5}$ Growth $+b_{6} G O+b_{7} K M+b_{8} R I S K+\varepsilon$

Keterangan:

DER = Struktur Modal perusahaan i pada tahun $\mathrm{t}$

a $\quad=$ Konstanta

$\mathrm{b}=$ Koefisien regresi

SA $\mathrm{i}=$ Struktur Aktiva perusahaan $\mathrm{i}$

ROA i $=$ Return On Assets perusahaan $\mathrm{i}$

Cr i $=$ Current Ratioperusahaan $\mathrm{i}$ 


$\begin{array}{ll}\text { Size } \mathrm{i} & =\text { Ukuran Perusahaan } \mathrm{i} \\ \text { Growth } \mathrm{i} & =\text { Tingkat Pertumbuhan perusahaan } \mathrm{i} \\ \text { GO i } & =\text { Peluang Pertumbuhan perusahaan } \mathrm{i} \\ \mathrm{KM} \mathrm{i} & =\text { Kepemilikan Manajerial perusahaan } \mathrm{i} \\ \text { RISK i } & =\text { Risiko Bisnis perusahaan } \mathrm{i} \\ \varepsilon & =\text { Residual error }\end{array}$

\subsubsection{Pengujian Asumsi Klasik}

Pengujian asumsi klasik dilakukan untuk memperoleh keyakinan bahwa penggunaan model regresi berganda menghasilkan estimator linear yang tidak bias (Algifari, 2000).

a. Pengujian Normalitas

Uji Normalitas untuk menguji apakah dalam sebuah model regresi, variabel dependen, variabel independen, atau keduanya mempunyai distribusi normal atau tidak (Ghozali, 2007).

b. Pengujian Autokorelasi

Uji autokorelasi bertujuan menguji apakah dalam model regresi linear ada korelasi antara kesalahan pengganggu pada periode $t$ dengan kesalahan pengganggu pada periode $\mathrm{t}-1$ (sebelumnya). Model regresi yang baik adalah regresi yang bebas dari autokorelasi (Ghozali, 2007).

c. Pengujian Multikolinearitas

Uji multikolinearitas untuk menguji apakah model regresi ditentukan adanya korelasi antara variabel independen. Jika variabel independen saling berkorelasi, maka variabel ini tidak orthogonal. Variabel orthoghonal adalah variabel yang nilai korelasi antar variabel independen sama dengan nol (Gozhali, 2007).

d. Pengujian Heteroskedastisitas

Pengujuian heteroskedastisitas bertujuan untuk menguji apakah dalam sebuah model regresi terjadi ketidaksamaan varians residual dari satu pengamatan ke pengamatan yang lain (Ghozali, 2007). Gejala heteroskedastisitas terjadi apabila disturbance terms untuk setiap observasi tidak lagi konstan, tetapi bervariasi. Model regresi yang baik adalah tidak terjadi heteroskedastisitas.

\subsection{Pengujian Hipotesis}

\subsubsection{Uji Hipotesis Secara Parsial (Uji-t)}


Pengujian secara parsial menggunakan uji-t (pengujian signifikansi secara parsial). Pengujian secara parsial ini dimaksudkan untuk melihat apakah pengaruh variabel independen secara individual terhadap variabel dependen signfikan atau tidak.

\subsubsection{Uji Hipotesis Secara Simultan (Uji F)}

Uji secara serempak atau untuk menguji ada tidaknya pengaruh yang signifikan pada variabel bebas secara simultan terhadap variabel dependen. Uji F merupakan pengujian terhadap koefisiensi regresi secara bersama-sama yang bertujuan untuk menguji apakah secara bersama-sama semua variabel independen memiiki pengaruh terhadap variabel dependen.

\subsection{Koefisien Determinasi $\left(\mathbf{R}^{2}\right)$}

Koefisien determinasi $\left(\mathrm{R}^{2}\right)$ mengukur seberapa jauh kemampuan model yang dibentuk dalam menerangkan variasi variabel independen. Nilai $R^{2}$ besarnya antara $0-1\left(0<R^{2}<1\right)$ koefisien determinasi ini digunakan untuk mengetahui seberapa besar variabel bebas mempengaruhi variabel tidak bebas. Apabila $\mathrm{R}^{2}$ mendekati 1 berarti variabel bebas semakin berpengaruh terhadap variabel tidak bebas.

\section{ANALISIS DATA DAN PEMBAHASAN}

\subsection{Pengujian Asumsi Klasik}

\subsubsection{Pengujian Normalitas}

Hasil uji normalitas dengan Normal P-P Plot menunjukkan bahwa angka probabilitas disekitar garis linier atau lurus. Artinya bahwa seluruh variabel yang digunakan dalam penelitian ini memiliki random data yang berdistribusi normal. Sehingga pengujian statistik selanjutnya dapat dilakukan baik uji-t maupun uji F.

\section{Gambar 4.1.}

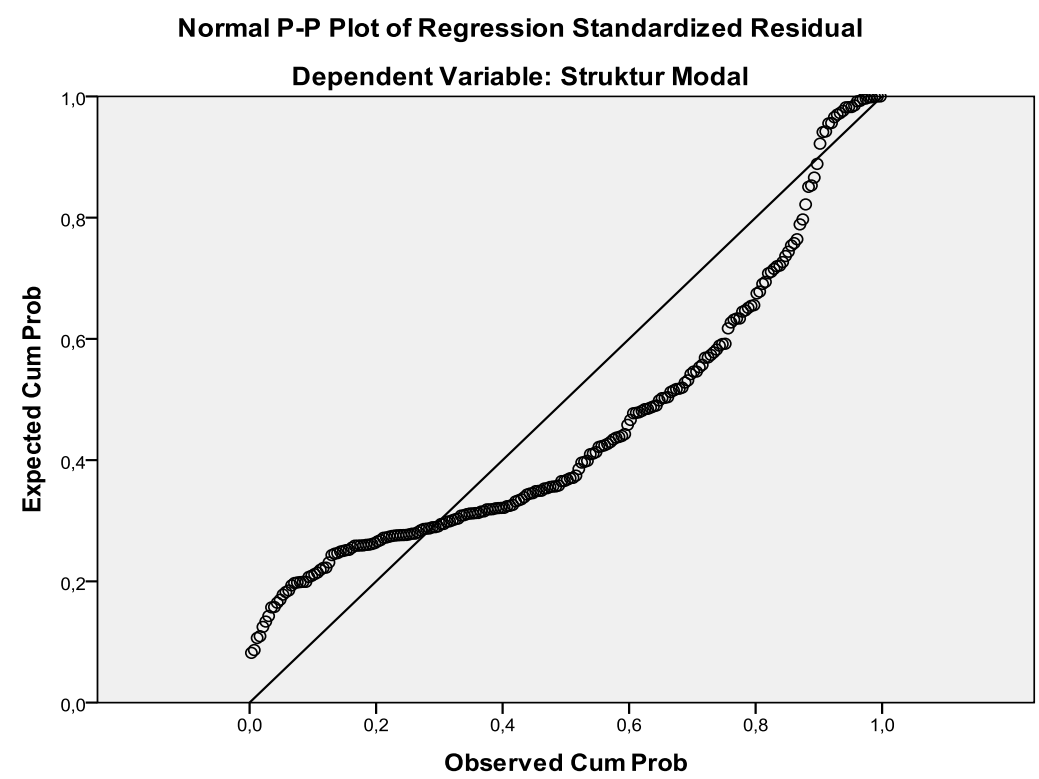

Sumber : Hasil olah data, 2013 


\subsubsection{Uji Autokorelasi}

Pengambilan keputusan ada tidaknya autokorelasi digunakan uji DW (Durbin Watson) dengan melihat koefisien korelasi DW test. Hasil perhitungan dengan SPSS 17.0, diperoleh nilai statistik Durbin Watson sebagai berikut:

Tabel 4.2.

Hasil Uji Autokorelasi dengan Durbin-Watson

\begin{tabular}{|l|r|r|r|r|r|}
\hline \multicolumn{7}{|c|}{ Model Summary $^{\text {b }}$} \\
\hline Model & $\mathrm{R}$ & R Square & $\begin{array}{c}\text { Adjusted R } \\
\text { Square }\end{array}$ & $\begin{array}{c}\text { Std. Error of the } \\
\text { Estimate }\end{array}$ & Durbin-Watson \\
\hline 1 &, $350^{\mathrm{a}}$ &, 122 &, 089 &, 3055826 & 1,815 \\
\hline
\end{tabular}

a. Predictors: (Constant), Resiko Bisnis, Kepemilikan Manajerial, Likuiditas, Tingkat Pertumbuhan, Ukuran Perusahaan, Profitabilitas, Peluang Pertumbuhan, Struktur Aktiva

b. Dependent Variable: Struktur Modal

Sumber: Hasil olah data, 2013

Hasil perhitungan di atas menunjukkan bahwa nilai DW test berada diantara nilai 1,66 s.d 2,34 yaitu dengan nilai DWtest sebesar 1,815 artinya tidak ada autokorelasi.

\subsubsection{Uji Multikolinearitas}

Multikolinearitas bertujuan untuk menguji apakah dalam model regresi ditemukan adanya korelasi antar variabel bebas. Pengujian adanya multikolinearitas dilakukan dengan memperhatikan besarnya tolerance value dan besarnya VIF (Variance Inflation Factor)(Ghozali, 2007). Jika nilai tolerance value $>0,10$ atau $<1$ dan VIF $<10$, maka tidak terjadi multikolinearitas. Hasil uji multikolinearitas disajikan pada Tabel 4.3 berikut:

Tabel 4.3.

\section{Hasil Uji Multikolinearitas}




\begin{tabular}{|c|c|c|c|}
\hline \multirow[b]{2}{*}{ Moc } & & \multicolumn{2}{|c|}{ Collinearity Statistics } \\
\hline & & Tolerance & VIF \\
\hline \multirow[t]{9}{*}{1} & (Constant) & & \\
\hline & Struktur Aktiva & ,902 & 1,109 \\
\hline & Profitabilitas & ,945 & 1,058 \\
\hline & Likuiditas & ,939 & 1,065 \\
\hline & Ukuran Perusahaan & ,921 & 1,086 \\
\hline & Tingkat Pertumbuhan & ,987 & 1,013 \\
\hline & Peluang Pertumbuhan & ,961 & 1,040 \\
\hline & Kepemilikan Manajerial & ,976 & 1,024 \\
\hline & Risiko Bisnis & ,996 & 1,004 \\
\hline
\end{tabular}

a. Dependent Variable: Struktur Modal

Dari Tabel 4.3. dapat diketahui hasil perhitungan dengan menggunakan SPSS 17.0, menunjukan bahwa nilai tolerance value $>0,10$ atau $<1$ dan VIF $<10$. Hal ini dapat disimpulkan bahwa persamaan model regresi tidak mengandung masalah multikolinieritas yang artinya tidak ada korelasi diantara variabel-variabel bebas sehingga layak digunakan untuk analisis lebih lanjut.

\subsubsection{Heteroskedastisitas}

Heteroskedastisitas muncul ketika varian dari distribusi probabilitas gangguan tidak konstan untuk seluruh pengamatan atas variabel penelitian. Metode yang digunakan untuk menguji heteroskedastisitas dalam penelitian ini memakai diagram scatterplot.

\section{Gambar 4.2.}

\section{Diagram Scatterplot}




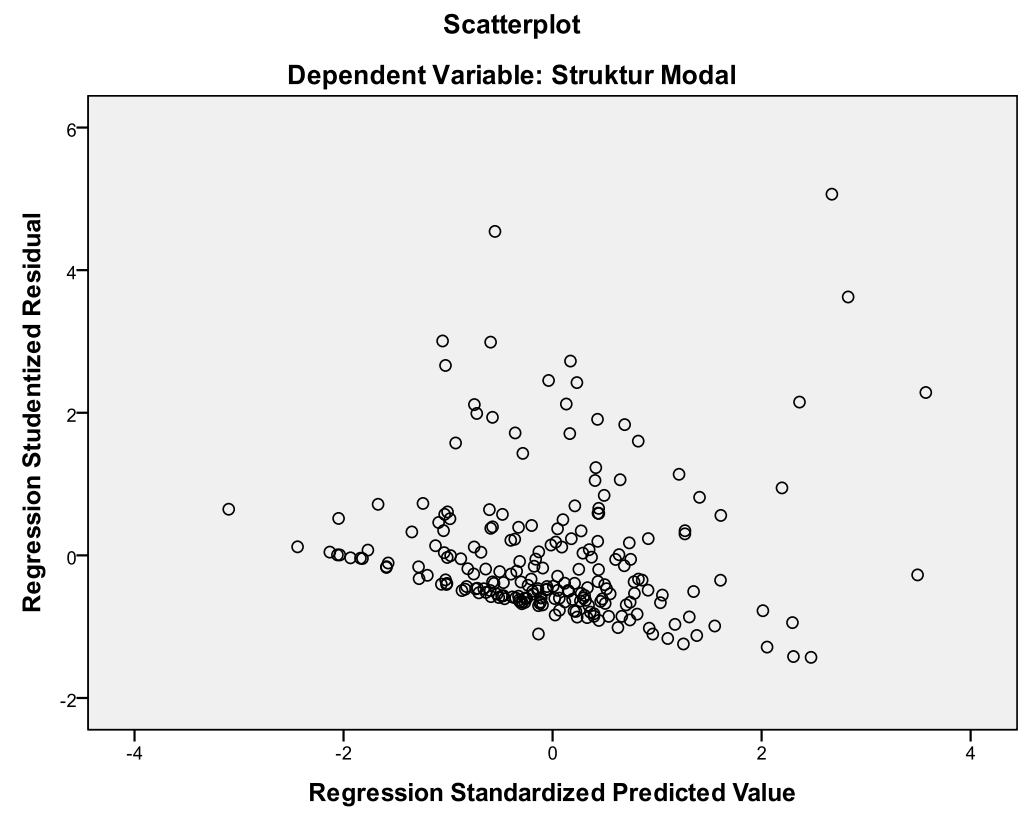

Sumber : Hasil olah data, 2013

Berdasarkan Gambar 4.2. dapat disimpulkan bahwa tidak ada pola yang jelas, serta titik-titik menyebar keatas dan dibawah 0 pada sumbu Y maka tidak terjadi heteroskedastisitas.

\subsection{Pengujian Hipotesis}

\subsubsection{Uji Hipotesis Secara Parsial (Uji -t)}

Berdasarkan Tabel 4.4. model regresi berganda untuk struktur modal perusahaan atas faktor-faktor yang mempengaruhi yaitu Struktur Aktiva, Profitabilitas (ROA), Likuiditas (CR), Ukuran Perusahaan, Tingkat Pertumbuhan, Peluang Pertumbuhan, Kepemilikan Managerial, dan Risiko Bisnis sebagai berikut:

DER $=-0,444+0,197 \mathrm{SA}-0,063 \mathrm{ROA}-0,003 \mathrm{CR}+0,035 \mathrm{SIZE}-0,006 \mathrm{GROWTH}+0,057 \mathrm{GO}$

$$
+0,037 \mathrm{KM}-0,002 \mathrm{RISK}
$$

Tabel 4.4.

Uji Hipotesis Secara Parsial 
Coefficients $^{a}$

\begin{tabular}{|c|c|c|c|c|c|c|}
\hline \multirow{2}{*}{\multicolumn{2}{|c|}{ Model }} & \multicolumn{2}{|c|}{$\begin{array}{l}\text { Unstandardized } \\
\text { Coefficients }\end{array}$} & \multirow{2}{*}{$\begin{array}{c}\text { Standardized } \\
\text { Coefficients }\end{array}$} & \multirow[b]{2}{*}{$\mathrm{T}$} & \multirow[b]{2}{*}{ Sig. } \\
\hline & & $B$ & Std. Error & & & \\
\hline \multirow[t]{9}{*}{1} & (Constant) &,- 444 & ,231 & & $-1,926$ & ,055 \\
\hline & Struktur Aktiva & ,197 & 077 & , 174 & 2,562 & ,011 \\
\hline & Profitabilitas &,- 063 & , 184 &,- 023 &,- 344 & ,731 \\
\hline & Likuiditas &,- 003 &, 003 &,- 080 & $-1,201$ & ,231 \\
\hline & Ukuran Perusahaan & ,035 &, 015 & , 157 & 2,329 & ,021 \\
\hline & Tingkat Pertumbuhan &,- 006 &, 014 &,- 030 &,- 457 & ,648 \\
\hline & Peluang Pertumbuhan & ,057 &, 018 & ,212 & 3,228 & ,001 \\
\hline & $\begin{array}{l}\text { Kepemilikan } \\
\text { Manajerial }\end{array}$ & ,037 &, 044 & ,055 & ,837 & ,403 \\
\hline & Risiko Bisnis &,- 002 & ,002 &,- 074 & $-1,148$ & ,252 \\
\hline
\end{tabular}

a. Dependent Variable: Struktur Modal

Sumber : Hasil olah data, 2013.

Hasil uji-t test dengan menggunakan program SPSS sebagai berikut:

1) Pengaruh Struktur Aktiva terhadap Struktur Modal (Debt to Equity Ratio)

Berdasarkan dari hasil perhitungan yang ditunjukkan pada Tabel 4.4. di atas, diperoleh nilai $P$ value hasil uji-t dari variabel struktur aktiva sebesar 0,011 . Dikarenakan nilai $P$ value lebih kecil dari tingkat signifikan $\alpha=5 \%$ atau $(0,011<0,05)$, maka Ho ditolak yang berarti variabel struktur aktiva secara parsial berpengaruh positif dan signifikan terhadap Struktur Modal (Debt to Equity Ratio). Secara umum perusahaan yang memiliki jaminan terhadap hutang akan lebih mudah mendapat hutang daripada yang tidak memiliki jaminan terhadap hutang. Aktiva tetap atau aktiva berwujud yang semakin besar akan menunjukkan kemampuan perusahaan dalam memberikan jaminan yang lebih tinggi, sehingga dengan mengasumsikan semua faktor lain konstan, perusahaan akan meningkatkan hutang untuk mendapatkan keuntungan dari penggunaan hutang.

2) Pengaruh Profitabilitas (ROA) terhadap Struktur Modal (Debt to Equity Ratio)

Berdasarkan dari hasil perhitungan yang ditunjukkan pada Tabel 4.4. di atas, diperoleh nilai $P$ value hasil uji-t dari variabel Profitabilitas (ROA) sebesar 0,731. Dikarenakan nilai $\mathrm{P}$ value lebih besar dari tingkat signifikan $\alpha=5 \%$ atau $(0,731>0,05)$, maka Ho diterima yang berarti tidak ada pengaruh Profitabilitas (ROA) terhadap Struktur Modal (Debt to Equity Ratio). Perusahaan dengan tingkat Return On Assets yang tinggi, umumnya menggunakan hutang dalam jumlah yang relatif sedikit. Hal ini disebabkan dengan Return On Assets yang tinggi tersebut memungkinkan perusahaan melakukan permodalan dengan laba ditahan saja. Return On Assets yang tinggi berarti bahwa laba bersih yang dimiliki perusahaan tinggi, maka apabila perusahaan menggunakan hutang yang besar tidak akan berpengaruh terhadap struktur modal, karena kemampuan perusahaan dalam membayar bunga juga tinggi (Kesuma, 2009).

3) Pengaruh Likuiditas (Current Ratio) terhadap Struktur Modal (Debt to Equity Ratio)

Berdasarkan dari hasil perhitungan yang ditunjukkan pada Tabel 4.4. di atas, diperoleh nilai P value hasil uji-t dari variabel Likuiditas (Current Ratio) sebesar 0,231. 
Dikarenakan nilai $\mathrm{P}$ value lebih besar dari tingkat signifikan $\alpha=5 \%$ atau $(0,231>0,05)$, maka Ho diterima yang berarti tidak ada pengaruh Likuiditas (Current Ratio) terhadap Struktur Modal (Debt to Equity Ratio). Hal ini disebabkan karena rasio likuiditas adalah rasio yang digunakan untuk mengukur kemampuan perusahaan dalam membayar hutang jangka pendek yang segera jatuh tempo. Berdasarkan pecking order theory, perusahaan yang memiliki likuiditas yang tinggi cenderung tidak menggunakan pembiayaan dari hutang karena perusahaan dengan tingkat likuiditas tinggi mempunyai dana internal yang besar, sehingga perusahaan tersebut akan mengunakan dana internalnya terlebih dahulu untuk membiayai investasinya sebelum menggunakan pembiayaan eksternal melalui hutang (Prowse, 1990 dalam Seftiane dan Handayani, 2011).

4) Pengaruh Ukuran Perusahaan terhadap Struktur Modal (Debt to Equity Ratio)

Berdasarkan dari hasil perhitungan yang ditunjukkan pada Tabel 4.4. di atas, diperoleh nilai $\mathrm{P}$ value hasil uji-t dari variabel Ukuran Perusahaan sebesar 0,021. Dikarenakan nilai $P$ value lebih kecil dari tingkat signifikan $\alpha=5 \%$ atau $(0,021<0,05)$, maka Ho ditolak yang berarti variabel Ukuran Perusahaan secara parsial berpengaruh positif dan signifikan terhadap Struktur Modal (Debt to Equity Ratio). Berdasarkan static trade off size atau ukuran perusahaan berpengaruh positif terhadap leverage. Hal ini disebabkan perusahaan dengan ukuran besar mempunyai risiko kebangkrutan yang kecil dibandingkan dengan perusahaan level yang lebih kecil. Semakin besar perusahaan maka perusahaan dapat memakai hutang lebih banyak, hal ini terkait rendahnya risiko pada perusahaan besar. Perusahaan dengan ukuran yang lebih besar dan kompleks tidak mempunyai kendala untuk mendapatkan dana eksternal (hutang). Oleh karena itu, kemungkinan tingkat leverage pada perusahaan besar akan lebih besar daripada perusahaan kecil. Semakin besar suatu perusahaan, ada kecenderungan untuk menggunakan jumlah pinjaman yang lebih besar (Christianti, 2006).

5) Pengaruh Tingkat Pertumbuhan terhadap Struktur Modal (Debt to Equity Ratio)

Berdasarkan dari hasil perhitungan yang ditunjukkan pada Tabel 4.4. di atas diperoleh nilai $\mathrm{P}$ value hasil uji-t dari variabel Tingkat Pertumbuhan sebesar 0,648. Dikarenakan nilai $P$ value lebih besar dari tingkat signifikan $\alpha=5 \%$ atau $(0,648>0,05)$, maka Ho diterima yang berarti tidak ada pengaruh Tingkat Pertumbuhan terhadap Struktur Modal (Debt to Equity Ratio). Tingkat Pertumbuhan adalah kemampuan perusahaan untuk meraih profit materi dan profit non-materi sesuai target. Jika manajemen mendukung tujuan pertumbuhan, kepentingan manajemen dan pemegang saham cenderung sependapat dengan perusahaan yang mempunyai kesempatan investasi yang kuat. Suatu perusahaan yang berada dalam industri yang mempunyai laju pertumbuhan yang tinggi harus menyediakan modal yang cukup untuk membelanjai perusahaan. Perusahaan yang bertumbuh pesat cenderung lebih banyak menggunakan hutang daripada perusahaan yang bertumbuh secara lambat (Brigham dan Gaperski, 1995).

6) Pengaruh Peluang Pertumbuhan terhadap Struktur Modal (Debt to Equity Ratio)

Berdasarkan dari hasil perhitungan yang ditunjukkan pada Tabel 4.4. di atas, diperoleh nilai $\mathrm{P}$ value hasil uji-t dari variabel Peluang Pertumbuhan sebesar 0,001 . 
Dikarenakan nilai $\mathrm{P}$ value lebih kecil dari tingkat signifikan $\alpha=5 \%$ atau $(0,001<0,05)$, maka Ho ditolak yang berarti variabel Peluang Pertumbuhan secara parsial berpengaruh positif dan signifikan terhadap Struktur Modal (Debt to Equity Ratio). Perusahaan yang mempunyai peluang pertumbuhan tinggi akan menghadapi kesenjangan informasi yang tinggi antara manajer dan investor luar tentang kualitas proyek investasi perusahaan. Adanya kesenjangan informasi tersebut menyebabkan biaya modal ekuitas saham lebih besar dibanding biaya modal hutang karena dari sudut pandang investor, modal saham dipandang lebih beresiko dibanding hutang. Kesenjangan informasi tersebut akan membuat para investor berisyarat negatif tentang prospek perusahaan di masa mendatang. Implikasinya adalah perusahaan akan cenderung menggunakan hutang terlebih dahulu sebelum menggunakan ekuitas saham baru. Perusahaan dengan pertumbuhan yang cepat harus banyak mengandalkan pada modal eksternal. Perusahaan dengan pertumbuhan yang tinggi cenderung lebih banyak menggunakan hutang dibanding dengan perusahaan yang lambat pertumbuhannya.

7) Pengaruh Kepemilikan Managerial terhadap Struktur Modal (Debt to Equity Ratio)

Berdasarkan dari hasil perhitungan yang ditunjukkan pada Tabel 4.4. di atas, diperoleh nilai $\mathrm{P}$ value hasil uji-t dari variabel Kepemilikan Managerial sebesar 0,403. Dikarenakan nilai $P$ value lebih besar dari tingkat signifikan $\alpha=5 \%$ atau $(0,403>0,05)$, maka Ho diterima yang berarti tidak ada pengaruh Kepemilikan Managerial terhadap Struktur Modal (Debt to Equity Ratio). Adanya partisipasi pemegang saham menjadi dewan direksi maka sebagian besar biaya yang akan dikeluarkan untuk ekspansi perusahaan akan diusahakan berasal dari hutang jangka panjang karena dewan direksi yang memiliki saham yang cukup besar dalam perusahaan akan lebih memprioritaskan pembagian dividen bagi para pemegang saham, hal tersebut akan semakin memperkecil struktur modal dalam perusahaan. Hal ini menunjukkan bahwa semakin tinggi kepemilikan managerial yang dimiliki perusahaan maka akan semakin rendah struktur modal perusahaan (Seftianne dan Handayani, 2011).

8) Pengaruh Risiko Bisnis terhadap Struktur Modal (Debt to Equity Ratio)

Berdasarkan dari hasil perhitungan yang ditunjukkan pada Tabel 4.4. di atas, diperoleh nilai $P$ value hasil uji-t dari variabel Risiko Bisnis sebesar 0,252. Dikarenakan nilai $\mathrm{P}$ value lebih besar dari tingkat signifikan $\alpha=5 \%$ atau $(0,252>0,05)$, maka Ho diterima yang berarti tidak ada pengaruh Risiko Bisnis terhadap Struktur Modal (Debt to Equity Ratio). Berdasarkan trade off theory, semakin tinggi kemungkinan financial distress, akan semakin tinggi pula kemungkinan financial distress costs yang harus ditanggung oleh perusahaan. Hal ini akan menyebabkan tingkat penggunaan hutang yang optimum semakin rendah, sehingga perusahaan seharusnya menggunakan lebih sedikit hutang. Meski demikian hasil penelitian ini pengaruhnya terhadap struktur modal tidak signifikan.

\subsubsection{Uji Hipotesis Secara Simultan (Uji F) dan Koefisien Determinasi $\left(\mathrm{R}^{2}\right)$}


Uji statistik F pada dasarnya menunjukkan apakah semua variabel bebas yang dimasukkan dalam model mempunyai pengaruh secara bersama-sama terhadap variabel terikat. Hasil uji F dengan menggunakan program SPSS sebagai berikut:

Tabel 4.5.

Pengujian Hipotesis secara Simultan

ANOVA ${ }^{\mathrm{b}}$

\begin{tabular}{|ll|r|r|r|r|r|}
\hline Model & & Sum of Squares & \multicolumn{1}{|c|}{$\mathrm{df}$} & Mean Square & F & Sig. \\
\hline 1 & Regression & 2,746 & 8 &, 343 & 3,675 &, $000^{\mathrm{a}}$ \\
& Residual & 19,703 & 211 &, 093 & & \\
& Total & 22,449 & 219 & & & \\
\end{tabular}

a. Predictors: (Constant), Resiko Bisnis, Kepemilikan Manajerial, Likuiditas, Tingkat

Pertumbuhan, Ukuran Perusahaan, Profitabilitas, Peluang Pertumbuhan, Struktur Aktiva

b. Dependent Variable: Struktur Modal

Sumber : Hasil olah data, 2013

Berdasarkan dari hasil perhitungan yang ditunjukkan pada Tabel 4.5. di atas, diperoleh nilai $\mathrm{P}$ value dari hasil uji $\mathrm{F}$ sebesar 0,000. Dikarenakan nilai $\mathrm{P}$ value lebih kecil dari tingkat signifikan $\alpha=5 \%$ atau $(0,000<0,05)$, maka Ho ditolak yang berarti variabel Struktur Aktiva,Profitabilitas (ROA), Likuiditas (Current Ratio), Ukuran Perusahaan, dan Tingkat Pertumbuhan, Peluang Pertumbuhan, Kepemilikan Manajerial, dan Risiko Bisnis secara bersama-sama mempunyai pengaruh yang signifikan terhadap Struktur Modal (Debt To Equity Ratio).

Dari Tabel 4.6. dapat diketahui besarnya koefisien determinasi berganda (Adjusted $\mathrm{R}^{2}$ ) sebesar 0,089, maka dapat diartikan bahwa 8,9\% Struktur Modal pada perusahaan Real Estate dan Property yang terdaftar di Bursa Efek Indonesia (BEI) dipengaruhi oleh kedelapan variabel bebas yang terdiri dari Struktur Aktiva, Profitabilitas (ROA), Likuiditas (CR), Ukuran Perusahaan, Tingkat Pertumbuhan, Peluang Pertumbuhan, Kepemilikan Managerial, dan Risiko Bisnis. Sedangkan sisanya sebesar 91,1\% dipengaruhi oleh variabel lain yang tidak dimasukkan dalam model penelitian.

Tabel 4.6.

Koefisien Determinasi

Model Summary

\begin{tabular}{|l|r|r|r|c|}
\hline Model & $\mathrm{R}$ & R Square & \multicolumn{1}{|c|}{$\begin{array}{c}\text { Adjusted R } \\
\text { Square }\end{array}$} & $\begin{array}{c}\text { Std. Error of the } \\
\text { Estimate }\end{array}$ \\
\hline 1 &, $350^{\mathrm{a}}$ &, 122 &, 089 &, 3055826 \\
\hline
\end{tabular}

a. Predictors: (Constant), Risiko Bisnis, Peluang Pertumbuhan,

Struktur Aktiva, Tingkat Pertumbuhan, Kepemilikan Manajerial,

Profitabilitas, Likuiditas, Ukuran Perusahaan

b. Dependent Variable: Struktur Modal

Sumber : Hasil olah data, 2013 


\section{KESIMPULAN DAN SARAN}

\subsection{Kesimpulan}

1. Berdasarkan hasil uji secara parsial menunjukkan bahwa variabel Struktur Aktiva berpengaruh positif dan signifikan terhadap Struktur Modal (Debt to Equity Ratio) pada perusahaan-perusahaan Real Estate dan Property yang terdaftar di Bursa Efek Indonesia (BEI). Semakin besar aktiva tetap yang digunakan maka perusahaan dapat menjaminkan aktiva tetapnya untuk mendapat pinjaman.

2. Variabel Profitabilitas (ROA) tidak berpengaruh signifikan terhadap Struktur Modal (Debt to Equity Ratio) pada perusahaan-perusahaan Real Estate dan Property yang terdaftar di Bursa Efek Indonesia (BEI). Return On Assets yang tinggi memungkinkan perusahaan melakukan permodalan dengan laba ditahan saja. Return On Assets yang tinggi berarti bahwa laba bersih yang dimiliki perusahaan tinggi, maka apabila perusahaan menggunakan hutang yang besar tidak akan berpengaruh terhadap struktur modal, karena kemampuan perusahaan dalam membayar bunga juga tinggi.

3. Variabel Likuiditas (Current Ratio) tidak berpengaruh signifikan terhadap Struktur Modal (Debt to Equity Ratio) pada perusahaan-perusahaan Real Estate dan Property yang terdaftar di Bursa Efek Indonesia (BEI). Perusahaan yang memiliki likuiditas yang tinggi cenderung tidak menggunakan pembiayaan dari hutang. Hal ini disebabkan perusahaan dengan tingkat likuiditas tinggi mempunyai dana internal yang besar, sehingga perusahaan tersebut akan mengunakan dana internalnya terlebih dahulu untuk membiayai investasinya sebelum menggunakan pembiayaan eksternal melalui hutang.

4. Variabel Ukuran Perusahaan berpengaruh positif dan signifikan terhadap Struktur Modal (Debt to Equity Ratio) pada perusahaan-perusahaan Real Estate dan Property yang terdaftar di Bursa Efek Indonesia (BEI). Perusahaan dengan ukuran yang lebih besar dan kompleks tidak mempunyai kendala untuk mendapatkan dana eksternal (hutang).

5. Variabel Tingkat Pertumbuhan tidak berpengaruh signifikan terhadap Struktur Modal (Debt to Equity Ratio) pada perusahaan-perusahaan Real Estate dan Property yang terdaftar di Bursa Efek Indonesia (BEI). Jika manajemen mendukung tujuan pertumbuhan, kepentingan manajemen dan pemegang saham cenderung sependapat dengan perusahaan yang mempunyai kesempatan investasi yang kuat. Suatu perusahaan yang berada dalam industri yang mempunyai laju pertumbuhan yang tinggi harus menyediakan modal yang cukup untuk membelanjai perusahaan.

6. Variabel Peluang Pertumbuhan berpengaruh positif dan signifikan terhadap Struktur Modal (Debt to Equity Ratio) pada perusahaan-perusahaan Real Estate dan Property yang terdaftar yang terdaftar di Bursa Efek Indonesia (BEI). Perusahaan dengan pertumbuhan yang cepat harus banyak mengandalkan pada modal eksternal. Perusahaan dengan pertumbuhan yang tinggi cenderung lebih banyak menggunakan hutang dibanding dengan perusahaan yang lambat pertumbuhannya.

7. Variabel Kepemilikan Manajerial tidak berpengaruh signifikan terhadap Struktur Modal (Debt to Equity Ratio) pada perusahaan-perusahaan Real Estate dan Property yang terdaftar di Bursa Efek Indonesia (BEI). Adanya partisipasi pemegang saham menjadi dewan direksi maka sebagian besar biaya yang akan dikeluarkan untuk ekspansi perusahaan akan diusahakan berasal dari hutang jangka panjang karena dewan direksi yang memiliki saham 
yang cukup besar dalam perusahaan akan lebih memprioritaskan pembagian dividen bagi para pemegang saham, hal tersebut akan semakin memperkecil struktur modal dalam perusahaan.

8. Variabel Risiko Bisnis tidak berpengaruh signifikan terhadap Struktur Modal (Debt to Equity Ratio) pada perusahaan-perusahaan Real Estate dan Property yang terdaftar di Bursa Efek Indonesia (BEI). Berdasarkan trade off theory, semakin tinggi kemungkinan financial distress, akan semakin tinggi pula kemungkinan financial distress costs yang harus ditanggung oleh perusahaan. Hal ini akan menyebabkan tingkat penggunaan hutang yang optimum semakin rendah, sehingga perusahaan seharusnya menggunakan lebih sedikit hutang.

9. Berdasarkan hasil uji secara bersama-sama (simultan) menunjukkan bahwa variabel independen yang meliputi Struktur Aktiva, Profitabilitas (ROA), Likuiditas (Current Ratio), Ukuran Perusahaan, Tingkat Pertumbuhan, Peluang Pertumbuhan, Kepemilikan Manajerial dan Risiko Bisnis berpengaruh terhadap Struktur Modal (Debt to Equity Ratio) pada perusahaan Real Estate dan Property yang terdaftar di Bursa Efek Indonesia (BEI).

\subsection{Saran} dilakukan:

Adapun saran yang dapat diajukan oleh penulis dari hasil penelitian yang telah

1. Untuk mengetahui keputusan pendanaan suatu perusahaan dalam menentukan besarnya penggunaan hutang atau modal sendiri, investor maupun emiten sebaiknya mempertimbangkan besarnya Struktur Aktiva, Tingkat Likuiditas, Ukuran Perusahaan dan Peluang Pertumbuhan perusahaan, terbukti dalam penelitian ini ketiga variabel berpengaruh signifikan terhadap Struktur Modal perusahaan Real Estate dan Property yang terdaftar di Bursa Efek Indonesia.

2. Bagi para peneliti lain yang ingin melakukan kajian ulang terhadap penelitian ini disarankan untuk menambah jumlah sampel pengamatan, periode pengamatan, jenis perusahaan yang berbeda serta setiap variabel dependen dan variabel independen lebih dari satu proxy.

3. Sehubungan dengan rendahnya pengaruh dari variabel-variabel yang digunakan dalam penelitian ini, maka peneliti selanjutnya dapat menggunakan variabel-variabel lain yang diperkirakan berpengaruh pada Struktur Modal (Debt to Equity Ratio) perusahaan Real Estate dan Property yang terdaftar di Bursa Efek Indonesia. 


\section{Daftar Pustaka}

Adrianto dan Wibowo, B. 2007. Pengujian Teori Pecking Order Pada PerusahaanPerusahaan Non Keuangan LQ45 Periode 2001-2005. Usahawan. No.12. Desember 2007.

Alwi, S. 1980. Alat-Alat Analisis dalam Pembelanjaan. Yogyakarta: Andi Offset.

Brealey, R. A. dan S. C. Myers. 2003. Principle of Corporate Finance. Seventh Edition. New York: McGraw-Hill.

Brigham, E, F. dan Gapenski, L, C. 1995. Intermediate Financial Management. Fifth Edition. Florida: The Dryden Press.

Brigham, E, F. dan Joel, F, Houston. 2001. Manajemen Keuangan. Edisi Delapan. Jakarta: Andi Offset.

Brown, K.C \& F.K Reilley. 2009. Analysis of Investments and Management of Portfolios. Edisi ke 9. Canada : South Western, a part of Cengage Learning.

Christianti, A. 2006. Penentuan Perilaku Kebijakan Struktur modal Pada Perusahaan Manufaktur di Bursa Efek Jakarta: Hipotesis Static Trade-Off atau Pecking Order Theory. Simposium Nasional Akuntansi 9, Padang, 23- 26 agustus 2006.

Chen, S. and Strange, R. 2006. The Determinants of Capital Structure: Evidence from Chinese Listed Companies. Economic Change and Restructring, 38, page 11-35.

Darminto. 2008. Pengujian Teori Trade Off dan Teori Pecking order dengan Satu Model Dinamis Pada Perusahaan Publik di Indonesia. Jurnal Manajemen Bisnis Vol 1 No. 1 Mei 2008.

Elsas, R. dan Florysiak. 2008. Empirical Capital Structure Research: New Ideas, Recent Evidence, and Methodological Issues. Discussion Paper at Munich School of Management. Munich, July 2008.

Erdiana, E. H. 2011. Analisis Pengaruh Firm Size, Business Risk, Profitability, Assets Growth, Dan Sales Growth Terhadap Struktur Modal (Studi Kasus Pada Perusahaan Real Estate and Property yang Terdaftar Di BEI Periode 2005-2008). Jurnal Ilmiah Manajemen. Semarang.

Fama, E. 2002. Testing the Pecking Order Theory of Capital Structure. Journal of Financial Economis.

Gaud. 2003. The Capital Structure of Swiss Companies: An Empirical Analysis Using Dynamic Panel Data. University of Geneva (HEC) finance research seminars, Geneva, 21 January.

Ghozali, I. 2007. Aplikasi Analisis Multivariate dengan Program SPSS. Cetakan Keempat. Semarang: Badan Penerbit Universitas Diponegoro. 
Groth, J. C. dan R. C. Anderson. 1997. "Capital Structure: Perspective for Managers", Management Decission, 35/7: 552-561.

Gitman, L, J. 2006. Principle of Managerial Finance. Eleventh Edition. Boston: AdissonWesley.

Hanafi, M. M. 2004. Manajemen Keuangan. Edisi Pertama. Yogyakarta: BPFE-UGM.

Harmono. 2009. Manajemen Keuangan: Berbasis Balanced Scorecard Pendekatan Teori, Kasus dan Riset Bisnis. Jakarta: Bumi Aksara.

Husnan, S. 2000/1996. Manajemen Keuangan Teori dan Penerapan (Keputusan Jangka Panjang). Buku 1. Edisi 4. BPFE. Yogyakarta.

Indrajaya. G, Herlina dan Setiadi. R. 2011. Pengaruh Struktur Aktiva, Ukuran Perusahaan, Tingkat Pertumbuhan, Profitabilitas dan Risiko Bisnis Terhadap Struktur Modal: Studi Empiris Pada Perusahaan Sektor Pertambangan yang Listing di Bursa Efek Indonesia Periode 2004-2007. Akurat Jurnal Ilmiah Akuntansi. No. 6 tahun ke-2 September-Desember 2011.

Indrawati, T. 2005. Determinasi Capital Structure Pada Perusahaan Manufaktur di BEJ 20002004. Jurnal Akuntansi dan keuangan Indonesia. Vol. 3 No. 1.

Kesuma, A. 2009. Analisis Faktor yang Mempengaruhi Struktur Modal Serta Pengaruhnya Terhadap Harga Saham Perusahaan Real Estate yang Go Public di Bursa Efek Indonesia. Jurnal Manajemen dan Kewirausahaan, hal. 40-41.

Lukas, S. A. 1999, Manajemen Keuangan, Edisi 2. Yogyakarta: Andi Offset.

Mardiana. 2005. Analisis Variabel-variabel yang mempengaruhi Struktur Modal pada Perusahaan Metal yang Go Public di Bursa Efek Jakarta. Jurnal Ilmiah bidang management dan Akuntansi. Vol. 2. No. 2.

Mirza, T. 1996. Return on Investment: Makna Dalam Proses Pengambilan Keputusan. Usahawan. XXV (5).

Modigliani, F. dan Miller, M. H, 1963. Corporate income taxes and the lost of capital: A correction. American Economics Review, June.

Myers, S, C. dan Majluf. 1984. "Corporate Financing and Investment Decision When Firm Have Information, Investor Do Not Have”, Journal of Financial Economics. 13.

Ozkan, A. 2001. Determinats of Capital Structure and Adjusment to Long Run Target: Evidance from Uk Company Panel Data. Journal of Business Finance and Accounting. 28 .

Pandey, I, M. 2004. Capital Structure, Profitability, and Market Structure: Evidence from Malaysia Asia Pacific Journal of Economics and Business. 8 (2).

Prabansari, Y. dan Kusuma, H. 2005. Faktor-faktor Yang Mempengaruhi Struktur Modal Perusahaan Manufaktur Go Public di Bursa Efek Jakarta. Sinergi. Edisi Khusus on Finance.

Riyanto, B. 2008. Dasar-Dasar Pembelanjaan Perusahaan. Yogyakarta: BPFE. 
Rodoni, A. dan Sholihah 2006. Pengujian Empiris Balance Theory, Pecking Order Theory dan Signaling Theory Pada Struktur Modal Perusahaan di Indonesia. Ekonomi. Vol. 5. No. 1.

Sartono, Agus. 2000. Manajemen Keuangan Edisi 3. Yogyakarta: BPFE.

Seftianne dan Handayani, R. 2011. Faktor-Faktor Yang Mempengaruhi Struktur Modal Pada Perusahaan Publik Sektor Manufaktur. Jurnal Bisnis Dan Akutansi, Vol. 13.

Setyawan, Hendri Sutapa. 2006. Analisis Faktor Penentu Struktur Modal: Studi Empiris pada Emiten Syariah di Bursa Efek Jakarta Tahun 2001-2004. Jurnal Akuntansi dan Keuangan. Vol.5,No.2 September.

Sinaga, Benni. 2009. Kitab Suci Pemain Saham. Jakarta: Duajari Terangkat.

Tong and J. G. Cristoper. 2004. Pecking Order or Trade off Hypothesis ? Evidence of the Capital Structure of Chiness Companies. Working Paper of Loughborough University.

Titman, S. dan Wessels, R. 1988. The Determinants of Capital Structure. The Journal of Finance, XLIII.

Wardani, H. K. 2010. Effect of Structure of Assets Size Companies, Profitability and Operating Leverage Against Capital structure in Company Property and Real Estate Listed in Indonesia Stock exchange (IDX). Undergarduate Program economy faculty Gunadarma University: Jakarta.

Weston, J, F. dan Copeland, T, E. 1999. Manajemen Keuangan. Edisi Kesembilan, Jilid Kedua. Jakarta: Binarupa Aksara. 